\title{
Embryo or Person? A Moral and Religious Dilemma
}

\author{
Dr. Reena Kannojiya \\ Assistant Professor, Department of Philosophy, \\ Miranda House, University of Delhi, Delhi-110007 \\ reena_kannojiya@yahoo.com
}

\begin{abstract}
In this paper, I inquire about the status of human embryo from ethico-religio perspective related to philosophical ideas and problems. The status of human embryo is perceived differently by scientists, moralists, and theists, which are essential to be carefully analyzed to make a judgment regarding the sanctity and identity of human race. The research based on human embryos is a delicate issue because at one end such kind of research efficacy to reduce human suffering and on the other end sanctity of human life is at stake. Therefore, it leads to develop moral and religious dilemma regarding embryonic usage for biomedical research. To value human race will help in avoiding wastage of human embryo and stressed over optimum use of stem cells by carrying out target orient research to develop therapies. Human embryo is a rich source of stem cells and easy to extract stem cells from it unlike an adult stem cell. It amounts to exploitation and misuse of human material. The exploitation of human embryo poses significant moral questions, 'Is embryo a person? 'Like person' Does embryo has right to life? With moral understanding, the religious understanding regarding embryonic research also discusses the status of an embryo from different perspectives. Various theistic and atheistic religions either approve the kind of research or disprove to be sinful. Every religion in its own concern of practices makes it a matter of human sentiment. Conclusively in this paper, I propose to discuss the moral and religious dilemmas to reconcile the scientific attitude with moral responsibility and religious sentiments to pave the path of human progress by reducing pain and suffering of physical form in this world.
\end{abstract}

\section{INTRODUCTION}

The quest for stem cell research creates a paradox between healthcare and the utilization of human material. Humans are considered to be at the highest order of the nature. So killing an embryo is a serious and debatable issue in regard with the potentiality as a person. Philosophically, it is a subject of critical screening or understanding in moral regard at one end and faith on the other end in relation with religion. Moreover, it is a controversial issue that needs critical scrutiny in order to maintain sanctity for human life. Hence scientists, philosophers, the logicians, government and private corporations should consider the issue to derive some conclusions about what should and should not be done with stem cells in ethical framework. The paper also highlights the issues involved in the problem from the ontology, morality and religious point of view regarding the status of embryo. These moral and religious both are the aspects of human life that regulates life of a person about right and wrong, good and bad in terms of faith he believes in. Basically biomedical research poses challenges to human life either by putting sanctity for human life in danger or by promising to reduce human suffering by curing or treating diseases. Both these challenges are difficult to be met at the same plane rather requires to wisely draw a line of control where human sentiments and religious beliefs can be reconcile with scientific necessities.

It is essential to know about the scientific terms, procedures, and implications involved in the issue for non scientific background of the people before discussing the status of embryo as 'Person', philosophically. Scientifically, stem cells are the point of origin of embryo. It raises a fundamental question what are stem cells? Stem cells are specialized cells from which all of the body's cell formed, mature and differentiated cells are made. These specialized get differentiated to give rise to brain cells, nerve cells, heart cells, pancreatic cells etc. hence there are two kinds of stem cells: embryonic stem cells and adult stem cells. Embryonic stem cells are also called "pluripotent" stem cells which are capable of developing into all the cell types of the body. Adult stem cells are less versatile and more difficult to identify, isolate, and purify. Now question arise what are the sources and method of obtaining stem cells. There are different sources and ways of obtaining and processing stem cells which are as follows: 
- The inner cell mass of blastocyst is the rich source of stem cells that can develop into all forms of normal cells and tissues; these are retrieved from the fertilized embryo which is formed by fusion of human egg and sperm from variety of donors during in-vitro fertilization process.

- Tissues of aborted fetuses or from terminated pregnancies and umbilical cord are the source of embryonic stem cell which is fully capable of producing all types of tissues.

- Cloning (somatic cell nuclear transfer) to obtain embryos that are genetic twins of the patients. The nucleus of a human or animal egg is replaced with the nucleus of an adult cell of a given human subject then directed to develop into the blastocyst.

These are the sources or ways of obtaining stem cells that is capable of forming any kind of organ tissue. The major ethical concern involves regarding the killing of embryo in retrieving stem cells. With this there are various other kind of ethical or moral concerns that disregard the commoditization of donors human egg and sperm, excess of fertilized eggs either destroyed or can be used for research purposes but involves the chances manipulation (cloning) and destruction of human material a disrespect towards the living entity and a would be potential person. Indeed, in this manner embryonic stem cell research poses a moral dilemma that forces us to choose between two moral principles:

- The duty to prevent or alleviate suffering.

- The duty to respect the value of human life.

In case of embryonic stem cell research, it is impossible to respect both moral principles because at one end in obtaining embryonic stem cells embryo at its early stage has to be destroyed. It means destruction of potential human life. At other end embryonic stem cell research could lead to the discovery of new medical treatments that would alleviate the suffering of many people. So which moral principle should have the upper hand in this situation? The answer hinges on how we view the embryo. Does it have the status of a person? Or Is embryo a 'Person'? Does it uphold full moral status?

To answer these ethical questions it is required here to critically analyze and scrutinize the arguments that can make clear the status of embryo. Hence the inquiry regarding the status of embryo involves the argument from the different fields of knowledge. It involves:

- Scientific argument

- Philosophical argument

- Religious argument

\section{SCIENTIFIC ARgUMENT}

Scientists and researchers argued that before implantation of blastocyst in the uterine wall an embryo is just a conglomeration of cells not a human life. It is considered that life begins with the fertilization of egg around day 14. So before this time a researcher can divide embryo in his laboratory to retrieve stem cells. Therefore, at this stage it did not contradict with the issue of killing an embryo. It is also argued in favour of stem cell research that up to embryonic day 14 the blastocyst has not developed with nervous system therefore cannot be considered as sensate. According to scientists first sensation begins with the formation of nervous system. Hence, it is the stage of embryo which comes at the lower end of living entities.

Michael $\mathbf{J}$ Meyer and Nelson $\mathbf{J}$ Lawrence argued that there is a hierarchy of respect due to living entities and conclude that an in vitro embryo comes low in this hierarchical scheme, are not entirely persuasive. It refers that in vitro embryo may get decline or diminish while implantation then the embryo implanted in the uterus and intended to become a human therefore it is at the highest order of hierarchical scheme of respect. It raises the issue regarding the fact when actually the life begins and on the fact that how one viewed regarding the order of hierarchical scheme of respect.

However, scientists and researchers believe that there is no moral issue occurs regarding the stem cell research because stem cells are being retrieved at the stage of implantation of blastocyst in the uterine wall, by the time life did not begins as it begins with the fertilization of egg around day 14 and it is not a sensate which intends to develop as a human. Moreover scientists believe in paving the stem cell research for discovering the cure or treatment of incurable diseases in order to reduce human suffering by reconciling moral issues for the use of human material. 


\section{Philosophical Argument}

Among all beings on earth, the human person is at the highest order of nature. Nevertheless it raises the question who is a person? Or what is the definition of 'Person'. Peter Singer defines person as the one who is self-conscious, rational, autonomous, and moral. St. Thomas Aquinas defined it in philosophical terms: the person is the "distinct being, subsisting in an intellectual nature." In this definition it combines two dignities-

- The dignity of independence in being.

- The dignity of reason or rationality.

On the basis of these two dignities raises precisely three questions:

- When exactly does the human person begin to be a person?

- When does the human embryo first have rationality?

- When does it first have subsistence or independence?

The answer of these questions needed a philosophical explanation and proof to establish embryo as a 'person' or not. The first argument proves the dignity of independence or subsistence in humans. It is assumed that the embryo is totally dependent on its mother to exist, so it cannot have the dignity of subsistence, or be a person until it separated from his mother at birth. This judgement of science is deceptive because we are confusing two kinds of dependence, biological and ontological:

- Biological dependence occurs at the very moment mother conceive for its nourishment until child takes birth.

- Ontological dependence is different. From the very instance of conception the foetus is living its own life, not like a member or an organ, which is an integral part of the maternal body but the embryo is not an integral part of her. Like a kidney or liver etc. He is a unique, complete unit, constitutionally distinct from the mother, and constitutionally autonomous in his own order. Hence, embryo upholds all the attributes of being a 'person'.

- The second argument comes from faculty of reason or the use of that faculty or nature. So a human child begins to use when he reaches to the age of five or six. But does it mean he does not have the faculty, how could he begin to use it? In truth, the child has reason dormant in him and takes few years to awaken. Faculty was born in him; it did not arrive at a later time. Therefore with all other elements of a being the faculty of reason also present in latent form since fertilization. Moreover, the embryo and foetus only differ developmentally from the infant; in the process of growth, he does not become fundamentally different as the development of the individual is a biological process in continuity of identity.

Hence man's rational nature, including the faculty of reason backs up then to very first moment of his conception or existence.

\section{Argument from Religions}

- Roman Catholic, orthodox, protestant churches- they affirm sanctity of human life at all stages of its development so according to them human personhood begins with the zygote which ultimately lead to a person.

- Liberal conservative protestant churches- they also believe that embryo has a status of potential human and sacred but embryo research might be allowed prior to the "primitive streak" stage (around $14^{\text {th }}$ day after fertilization) bearing in mind the seriousness of certain medical conditions that could possibly be treated.

- Judaism- they firmly believe in healing and world's repair. So this comes in support of embryonic stem cell research and in Judaism the human foetus less than 40 days old i.e. pre-implantation embryo does not have a full human status but after 40 days the embryo is the part of the woman until birth.

- Islam- majority of Muslims accepted the morality of abortion before either the $40^{\text {th }}$ or the fourth month of pregnancy because it is believed that the soul is "breathed in" to the embryo on the $40^{\text {th }}$ 
day after fertilization and this is when life becomes sacred and a moral person but supernumerary embryos cannot be donated to other couples, as the lineage of the father must be respected.

- Buddhism and Hinduism- Buddhism prohibits harm to any sentient beings and every action of killing that treats humans as non-beings is considered immoral however, research on molecular human part such as cells is morally acceptable as far as there is a problem of suffering is to be removed but if research is done for the sake of money making out of it, it is unethical. Hinduism, like Buddhism prohibits injuring sentient beings rejects both animal research and the destruction of sentient embryos.

Conclusively, there are certain religions that support the moral principles to alleviate human suffering to an extent by recommending embryonic stem cell research.

The discussion regarding the morality of embryonic stem cell research in relation with the status of embryo as a living entity and Personhood leads to evolve with certain arguments in favour and certain in against of embryonic stem cell research it in form of ethical debate. These ares-

\section{FAVOUR}

- Embryonic stem cell research fulfills the ethical obligation to alleviate human suffering.

- Since excess IVF embryos will be discarded anyway, isn't it better that they be used in valuable research?

- SCNT (Therapeutic Cloning) produces cells in a Petridis, not a pregnancy.

\section{Against}

- In ESCR, stem cells are taken from a human blastocyst, which is then destroyed. This amounts to "murder."

- There is a risk of commercial exploitation of the human participants in ESCR.

- Slippery slope argument: ESCR will lead to reproductive cloning.

Embryonic stem cell research worldwide:

- In the European Union, stem cell research using the human embryo is permitted in Sweden, Finland, Belgium, Greece, Britain, Denmark and the Netherlands

- Supportive Countries: United States, Japan, India, Iran, Israel, South Korea, China, and Australia.

- It is illegal in Germany, Austria, Ireland, Italy, and Portugal.

- New Zealand, most of Africa (except South Africa), and most of South America (except Brazil) are restrictive.

Consequently, the only morally licit path open is to continue research on adult stem cells because such research impairs the use of their organs, members, intelligence and free will rather than compromises the life of the subjects.

\section{REFERENCES}

[1] Hug K (2006). Therapeutic perspectives of human embryonic stem cell research versus the moral status of a human embryo - does one have to be compromised for the other? Medicina (Kaunas)

[2] Guidelines of Indian Council of Medical Research, chapter- vii

[3] Fr. Juan Carlos Iscara (2000). The immorality of embryonic stem cell research, originally issue of The Angelus

[4] Singer, Peter (2000). Practical Ethics, the University of Cambridge, 